\title{
Once a Supermarket Cashier
}

\author{
Yi Zhang
}

\section{Interview with Miss S's Mother}

Miss S. Female, born in 1983, only child, has moderate intellectual disability. She graduated from a regular technical secondary school in Shanghai and once worked at a supermarket. From 2008, she joined a Sunshine Home of a subdistrict in Shanghai.

Interviewee: Miss S's mother.

Interviewer and writer: Yi Zhang.

Interview dates: October 21, 2016 and January 1, 2017.

Interview place: Sunshine Home of a subdistrict in Shanghai; Tian Jiabing Building, Eastern China Normal University.

\section{Dangerous Childbirth}

Q: How did you meet your husband?

S's mother: My husband and I both studied at a vocational school in two different classes.

Q: What did you learn?

S's mother: You know, there is a factory in Shanghai making towels and sheets. My husband learned pattern design of towels, while I learned cotton textile. After graduation, he was assigned to the suburban area. Some of his classmates were assigned to Chuansha and Jiading, and later came back to Shanghai.

$\mathrm{Q}$ : When did you get married?

Y. Zhang $(\bowtie)$

East China Normal University, 3663 Zhongshan Bei Ro., Shanghai 200062, China 
S's mother: In January 1983, about 6 years after our graduation. Both of us have several siblings. At that time, there was a shortage of apartments in Shanghai. So, we were mainly waiting for an apartment before we got married.

Q: Did you get pregnant immediately after getting married?

S's mother: About 2 months later. Everything was normal. The expected due date was November 15, but she didn't come out until November 20, 1983.

Q: Did you have any expectations before the delivery?

S's mother: I didn't expect anything like this. None of my colleagues, friends, and sisters encountered such a situation. My sisters gave birth to big babies. My eldest sister's baby was more than $4.5 \mathrm{~kg}$; my other sister's baby was over $4 \mathrm{~kg}$. Both babies were healthy. My baby was $3.9 \mathrm{~kg}$ at birth. Everything was normal during my pregnancy.

At that time, every family had many children, so the doctors and nurses were not as responsible and careful as they are now. It seemed that they didn't take it seriously. During my hospitalization, I shared a bed with another woman before delivery; I was sent to the delivery room when I was going into labor, and I had a whole bed to myself after delivery. There weren't enough beds.

I gave birth at the Second Textile Hospital, the designated hospital for employees in our factory.

I went to the hospital with obvious signs of labor, but my cervix remained closed during my first days there. Though both of my sisters gave birth by C-section, my mother warned me against it, as she thought a $\mathrm{C}$-section could do harm to my health according to her old and conservative opinions.

I had no experience at all. I just thought that my mom must know something, since she had given birth to six children. After entering the delivery room, it actually hurt so badly, but I was too embarrassed to cry out loud. I just endured silently. Because of this, I received basically no attention from the doctors and nurses. I entered the delivery room in the evening, but I was still showing no sign of the delivery starting until the next morning. The doctors said that my cervix was not open. I really didn't understand anything back then.

The pain became unbearable the next evening. After disinfecting my skin, the nurse in the delivery room told me to lie on the delivery bed and simply said, "Go ahead." Then everyone left. This was strange. I had thought that there would be someone to help me during labor. How could they just leave me alone? It was a little past $5 \mathrm{pm}$, when they needed to hand over to the next shift. All of them went to the dressing room, thinking that I was giving no sign of going into labor, so it was okay that they took this time to get changed. My daughter was later delivered at 6:30. Before that, I felt a severe pain in my belly. That was a contraction, and the abdomen should be bloated according to the doctors. They would also ask me, "Does your belly feel bloated?" But it didn't. I couldn't understand what that should feel like. Though I had learned something about labor, I never discussed it with others. I knew little about it. The pain was not continuous, not that acute, just labor pains. I thought, "Maybe every mother feels like this." So, I just endured. I could hear them talking in the delivery room, feeling that something was pushing its way out of my belly, like 
going to the bathroom. In fact, the baby had come out. But nobody was there to hold her, so, she went back in.

I guessed the doctor who sent me to the delivery room had got off work, as I heard a cry from the doctors on duty, "Oh my gosh! What happened? How come there is no fetal heartbeat? Hurry!!" The two doctors were nervous. One of them pressed my body from the chest to the belly. Then, they seemed to put on rubber gloves, reached into my belly for her and tried to pull her out, but they failed. Ultimately, they used forceps to get her out.

When she was out, I thought everything was fine, as I had no previous experience. I only knew that newborn babies should cry, but I didn't hear it. I raised my head (turning the head slightly), trying to have a look, but the doctor said, "Don't move. Lie down." To make my baby cry, they lifted her by her feet and patted her on the bottom for quite some time before she gave a feeble cry. After that, the doctor told me immediately, "A girl," and also weighed her on a scale before telling me her weight. I raised my head and finally saw my daughter; her face being partially covered with blood. I saw this for the first time. Seeing that I couldn't see her clearly, the doctor said, "She has newborn jaundice. Her condition isn't that good." As no doctors in the delivery room could treat my daughter, she was wrapped by a doctor and taken to the pediatrics department right away for emergency treatment.

I was left alone and unattended in the delivery room. I heard something dripping down into the bucket below the bed, but I didn't know it was actually blood from my belly. It was November 20, already very cold in Shanghai, but there were no air conditioners, only heating pipes on the wall. I simply wore a thin top, no pants, with a diaper on my belly, waiting for the doctors to come back and stitch my incision into the perineum. They had cut it to make my delivery easier... Unfortunately, that was painful. After the wound was stitched, I stayed in the cold delivery room for two more hours for observation before I was finally transferred to a ward. My feet were almost completely covered in blood when I got out of the delivery room. Back then, no one helped you get changed.

At that time, there was no bathroom in the ward. The next day, the catheter came out when I turned over and I had to use the public restroom in the corridor. It took a lot of effort to get to my feet and I had a difficult time trying to stand, because I was bleeding heavily. Then I just fainted in the restroom. I didn't care, though. All I cared about was my daughter.

After emergency treatment at the pediatrics department, my daughter was sent to a nursery opposite the ward. Due to inadequate conditions, all the babies slept together in a big bed the size of a big table. Perhaps to facilitate emergency treatment, my daughter was put on one end of the bed, closest to the door. I often went to check her through a small window on the door whenever I had the chance. Normally, newborn babies were swaddled, while my daughter was not, because she needed frequent medical check-ups. As she stayed in the nursery, I couldn't breastfeed her. She was fed with a bottle with a rather big nipple, which was actually easier for babies to suck. But my girl was too little. She couldn't swallow the milk, but stored it in the esophagus. Since her cardia wasn't well developed, the milk was often spat up. Therefore, the doctors didn't allow her to lie flat. She was tilted about 20 degrees 
head-up like this. I often went there to check on her. All the other babies could be taken out for breastfeeding, so I asked the doctors why my daughter was kept inside. They only told me that she had jaundice, mentioning nothing else. I knew nothing, either. I just thought she would get well anyway. I only needed to wait for a few days.

In the end, she couldn't come out even after I was discharged. The doctors hid the truth from me, but told my husband that my daughter might not live for long. Back then, newborn babies were usually scored from 0 to 10 by the hospital. My daughter was 0 . She had no heartbeat, and simply gave a cry even after an injection of cardiotonic. By current practice, hospitals won't try to rescue her at all. But as the designated hospital for the large number of female employees in our factory, this hospital had quotas for C-section delivery, birth rates, and death rates. By November 20 , namely the end of the year, the hospital already had no death quota, and as such they tried their best to save my child to meet the required birth rate. The doctors told my husband that due to her precarious health, she needed to stay at the hospital for observation, which lasted for about 1 month.

Q: So, your daughter wasn't with you in the month following her birth?

S's mother: While I was in postpartum confinement, my husband checked on her every day after work, telling me she was good today, and became worse another day. If I had known better, I would have forfeited her treatment. My husband told me, "The doctors said that she was recovering." I said, "As long as she recovers and she's alive, take her home." I didn't expect the following bitter experiences. I just thought I should take her home if she was healthy. After all, she came out of my womb after the long months of pregnancy. I even prepared some clothes for her, in case she didn't survive- - she came into this world naked, but I wanted her to be dressed when leaving. Now that she was rescued, I took her home. At that time, she was less than 28 days old.

\section{Fragile and Listless Due to Illness}

S's mother: She was hospitalized again when she was 28 days old.

Q: Why was that?

S's mother: This is her medical record back then (showing the brochure). She suffered from neonatal pneumonia more than five times. Then she had severe asthma and was treated with a new medicine called cefradine. After that, she had stomach bleeding and was admitted to the hospital again, where we received a notice of critical condition. We were issued such notices eight or nine, if not ten times. In those days, my husband always worked overtime on weekends so that he could take her to the hospital on weekdays. He never rested on weekends after my daughter was born.

The household registration of my daughter and I were both recorded in the same register as my mother in Yangpu District, while we lived several districts away in Luwan District. At that time, one could only go to the hospitals in the same district as the household registration. So, what could we do if my daughter had a fever seizure at midnight? With barely no taxis, we had to take the night bus, which came once 
an hour. We frequented the hospital at midnight. When she had to be hospitalized, she was also admitted to a hospital near our registered residence. But again, the milk I ordered was delivered to Luwan District, so I had to get the milk early in the morning, take it to the hospital, and leave the hospital after she finished. Parents weren't allowed to stay with kids. It was tough for us.

Q: Why were parents not allowed to stay at the hospital?

S's mother: When she was little, the IV was placed in her scalp. She didn't even have any hair when she was 100 days old (showing the photo). She always needed IV therapy. On these occasions, she was taken to another room where parents were not allowed, as the steps were difficult and the sights could be horrible. Anyway, my daughter spent her childhood going in and out of the hospital and taking medicine. She was hospitalized many times. Each time she was discharged, the doctor would write in her record that "this kid is intellectually disabled". I was always so mad to see the words "intellectually disabled" that I would cross them out. I felt reluctant to accept the fact, thinking about why they had to draw this conclusion when my daughter didn't come to the hospital for this. I was sad to see the note at that time. This one is from 1992. You see (flipping through a medical record), every medical record contains a similar statement. Whatever. I just hid the record at home and I wouldn't show it to other people.

Q: Did the doctors conduct any tests before coming to such a conclusion?

S's mother: No. They simply concluded based on what they saw. At that time, my daughter's eyes looked...

Q: They only judged by appearance?

S's mother: Right. But I didn't consider her as intellectually disabled.

Q: What was she like after she was discharged from the hospital?

S's mother: Her health had been poor ever since. Her cardia became normal only when she was much older. As my husband had to work, I needed to take care of her by myself. After each feeding, I had to pat her for half an hour before I could lie her down into the bed. But soon after I left for other chores, she would spit up, with vomit in her eyes, ears, and around her neck. In those cases, she needed a hot bath even in the cold winter days, when there was no proper device except for a plastic cover. No one could help me. I had to light the coal stove and get her changed on my own, leaving no time for me to eat. I just had to constantly keep an eye on her. When I wanted to start cooking as the stove was hot enough, she would vomit again. After I cleaned her for the second time, the stove had already gone out. Thus, I didn't have any time to cook at all. I didn't have much entertainment, either. I never watched TV. We couldn't afford our own TV until my daughter was 3 years old.

Always ill and listless, she didn't have enthusiasm for anything. For example, when she woke up and I took her downstairs, my neighbor would say, "Ah, Mrs. Zhou, why is your daughter sleeping?" It seemed that her eyes were always narrowed, but the truth was that she didn't have enough strength to open up her eyes. She always looked ill. I could only joke that, "My daughter has small eyes."

She was late in talking and toddling. Due to illness, she remained weak. She often tripped over and fell while walking. In the past, old houses in Shanghai had garrets, the door of which led to the staircase. I installed a small door in addition to the main 
entrance, so that she could see me from the garret through the closed small door while I was working downstairs. But she wanted to go downstairs when she grew older. I told her, "Come down here, but be careful, hold the stairs." Then she would come down, with her feet followed by her bottom.

The coal stoves heated up quite slowly. To make it faster, my neighbor made something like a chimney with iron sheets and put it in above the stove to attract the wind. After the fire was made, this object was placed next to our staircase. My daughter fell down the stairs while she was trying to come down, and her forehead was scratched on the iron sheet (pointing at the forehead). She started bleeding and I could even see her flesh. In those days, we had good neighborhood relationships. I yelled "uncle", then my neighbor immediately carried my daughter to the hospital. I followed as well. It was late. There was no emergency treatment at the ophthalmological department. So, we went to the surgical department, where a doctor asked me and my neighbor to fix her head and feet respectively, cleaned the wound roughly and stitched her wound without any anesthetics. The stitches were very long. The ash was even left inside. Until now, this tiny scar still remains above one of her eyebrows with the dust inside.

Considering her situation, I proposed to change to another job in Luwan District as no one could help me. At my home, though I got married, I had five other siblings, so my mother still shouldered a heavy burden. She had to work and take care of my younger sisters and brothers. As for my mother-in-law, she had three other sons to take care of. In terms of commute, I needed to set out every day from my home in Luwan District, took the bus, transferred the routes twice, and took at least $2 \mathrm{~h}$ before I arrived at the office on the Jungong Road in Yangpu District. I also needed to work early shift, noon shift, and night shift. I was allowed to take 1 year off to take care of my daughter after she was born, but I had to go back to work when my leave ended. How could I do that with my daughter ill at home? So, I changed to a different job in Luwan District, which was near my home.

\section{Hard Days in the Kindergarten}

\section{Q: Did she go to kindergarten?}

S's mother: Our factory has its own nursery and kindergarten. I took her to the kindergarten when she was the right age. There were two aunts taking care of many kids there. They either put my daughter in a chair designed to prevent falls by making her sit down before she might fall, or tied her to a small chair with a spittoon under it to prevent her from falling off. My heart hurt at the sight, but I had no choice. If I complained, the aunts would say, "How about taking her home and looking after her yourself?" So, I could only bear with it, leaving her in the kindergarten.

Over time, when people in the kindergarten realized that there seemed to be something wrong with my daughter, they kept asking me to take her to do an IQ test. The head of the clinic of our factory told me, "Take your daughter to test her IQ and see how it is going." 
I was disgusted and couldn't understand why they treated her like this. I thought maybe they wanted to drive my daughter out of the kindergarten. But I really had no other choice. The current arrangement was the most convenient option for me, because I could take her there on my way to work and pick her up when I got off. If I had to send her to a kindergarten for kids with ID, she would have been worse off. So, I just procrastinated.

I was aware that she had some shortcomings, but I just couldn't face it. I never considered her as an intellectually disabled kid. I am a person of strong character. In my opinion, she was just dim-witted, since kids may vary in their intellectual level. I believed that slow birds should fly ahead. Actually, it was painful to have a kid like this. I knew the kindergarten intended to drive my daughter to a special kindergarten with the excuse of the IQ test, but I decided to not let them succeed. I just kept on refusing their demand.

The kindergarten was not well equipped. Outside the classrooms, there was a long corridor. Next to the corridor was a balcony with square columns. Once, her teacher was sitting there, legs crossed, and chatting with others. My daughter tripped and bumped against the edge of a column. A new vertical scar was thus added to her original horizontal one. The clinic of our factory used a new medical glue to treat it. Though no stitches were needed, the wound would open when my daughter cried. I said, "This is not working at all. You must take her to the hospital!" Again, she got more than ten stitches. You can still see the scar now. "I was really sad," no parent could bear to see their kids injured like that.

After she was discharged from hospital, the factory granted me a leave of several days to take care of her. At this moment, the leaders of the kindergarten visited us, trying to convince us not to take my daughter back to their kindergarten, because they "couldn't shoulder the responsibility". This was ridiculous. I didn't even have the chance to complain about it. So, I firmly refused their requirement to send my daughter to a special kindergarten. At last, we negotiated an agreement with this affiliated kindergarten through my supervisor, saying that we would be responsible in case my daughter had any further problems.

During that period, my daughter was ill and hospitalized; my husband still worked overtime so as to be able to accompany her on weekdays, while I brought dinner to the hospital after getting off work. This was because my meagre salary would be deducted if I took leave. During 8 weeks of hospitalization, I visited my daughter every day. It was lucky that my factory understood my difficulties, granting me leave if we weren't that busy.

I knew that kids would start to learn to read and acquire new knowledge in kindergarten, but as a slow learner, my daughter wouldn't be able to keep up. The first day she was admitted to the kindergarten, I enrolled her in an afterschool pinyin class at my own expense, because I believed that this was very important. At that time, kids didn't learn pinyin before primary school. I wanted my daughter to learn earlier. It turned out to be helpful.

In the meanwhile, we kept taking my daughter to Ruijin Hospital at our own expense. The doctor kept a record of my daughter from her birth to 3 years of age, according to which he found that my daughter had been improving. The doctor always 
encouraged us, "Other kids may learn quickly after being taught once or twice, but she can also learn if you teach her 10 times, or even 30 times. It will work." Thanks to this, we always had hopes of my daughter getting better. With her dad and me taking care of her, she wouldn't encounter difficulties at school. Otherwise, we would have given up over time.

Q: Did she like the kindergarten?

S's mother: No, but she had no choice. There was nobody at home to take care of her. Simple-minded and timid, she didn't talk much about things in the kindergarten. Once, we met her aunt. She worked in a hair salon in Hong Kong and braided my daughter's hair. It was beautiful, no one had ever seen it before. But when my daughter returned from kindergarten, she told me that people gossiped about her looks. She couldn't understand why her teacher criticized her hairstyle and asked other kids not to play with her, while other people said it was pretty. Her dad was furious. He questioned the teacher the next day when he took her to the kindergarten, "How could you treat her like that?" Of course, the teacher denied it. My husband failed to control his temper and they had a quarrel. Later, I tried to mitigate the conflict and explained, "My husband is ill-tempered. There must be some misunderstanding because my daughter didn't communicate clearly enough..." There was no use. The teacher continued to ignore my daughter and asked other kids not to play with her. My daughter was left alone in a corner whenever they were having some activities.

Once, all the other kids in her class went to a supermarket to learn about vegetables, but my daughter was sent to the junior class. During the break, the kindergarten required everyone to pee together. My daughter didn't want to pee at that time, but she wanted to defecate during the class, which wasn't approved by the teacher. Eventually, she pooped her pants. It was a cold winter day. When I got off work and saw her pooped pants, I had to borrow a pair of padded pants from my colleague who lived nearby and take my daughter to have a shower in the bathhouse of the factory. I had no choice but to put up with it.

In another case, my daughter was left alone again in the junior class. The teacher of that class also felt upset, just asking her to sit alone in the yard, where the teacher could see her through the door of the classroom. I happened to check on her during spare time, as I didn't feel reassured. "This is strange, where's my daughter?" "In the junior class." "But she wasn't there, either!" Then suddenly, I saw her... I couldn't complain to anyone, because she had to stay there. Anyway, I felt depressed at that time. Few people seemed to have any sympathy for us.

Due to illness, she was weak and had a poor appetite. She didn't like the food and would always cry at lunch. I saw it many times that my daughter didn't want to have dinner. So, I told her teacher, "Please don't give her so much food. Just take it away if she doesn't eat. Don't force her." Every time when I went to the kindergarten to check on my daughter after lunch as my work at the canteen was done, I saw my daughter standing and eating next to the trashcan containing leftover food, with a bowl of cold rice in her hand. It was already $1 \mathrm{pm}$. Who could bear to see this? I was really angry, but still, I couldn't complain. It wouldn't work. I just emptied the bowl and told my daughter to give the bowl to her teacher, but she didn't dare to. Then I took the bowl and tossed it on the desk without a word. What could I say? 
Q: Did her teacher punish her because she didn't finish her meal?

S's mother: They always forced her like this. I had told them to give her less or take her meal away if she was full. I wouldn't blame them for it. I could still feed her after school if she was really hungry. But they wouldn't listen. I already treated them well enough. When they came to the canteen during lunchtime, I gave them more food in larger bowls. We seemingly got along well, but they despised my daughter. The nutritionist of the kindergarten's separate canteen always looked at my daughter like this (showing an expression of disgust), so did her teacher in charge. I felt upset, but I couldn't say anything, or my daughter would suffer more.

Q: Did this situation continue throughout her days at the kindergarten?

S's mother: Yes, but she also met some good teachers. Teachers would change from junior class to the senior one. When she was in the senior class, a teacher surnamed $\mathrm{Xu}$ and an old aunt were very kind to her. In the music class, my daughter could hum the prelude after the teacher just taught them a song for several times. This attracted the teacher's attention, who pulled my daughter closer to observe her carefully. Though my daughter was simple-minded, she could understand it. She would take her stool and sit really close to this teacher when everyone was sitting on the small playground, for example, because she knew the teacher was kind to her. The teacher found her adorable despite the intelligence level, so the teacher encouraged her and told her, "My dear, you can do it." Because of this, she enjoyed her days in the senior class.

Q: Did she like singing?

S's mother: Her teacher found that she could hum the prelude, I discovered her interest in singing, too. As we didn't have a karaoke machine at home, she liked to sing on her bed like this (gesture with hands), pretending to hold a microphone in her hands. Later, I managed to buy a stereo so that she could sing to music. She learned to talk much later than other kids. I still encouraged her to sing even though she wasn't good at it and couldn't sing clearly. People often said, "Oh, she doesn't sing well. I can't even understand the words." I replied nothing. I was used to that kind of comment. I didn't take them seriously. I just told her to sing whenever she liked. She can sing pretty well now.

\section{Study Late into the Night}

S's mother: As she grew older, she needed to attend primary school in Yangpu District. She had just recovered from stomach bleeding by then. How could I take care of her while having to go to work in another district? So, I asked my mother-in-law, "Would it be possible to transfer my daughter's household registration to your residence? I promise I'm not after your house. I know it's for my brother-in-law. I only want my daughter to go to school here." She agreed.

This way, my daughter was admitted to a school affiliated to the railway system not far from my mother-in-law's home. The teachers there were relatives of the railway staff. They were really nice. As they only knew that my daughter was weak, but 
nothing about her previous story, they took good care of her, and often praised her even for minor progress. She was good at pinyin. This was the only exam that she got 100. In the first semester of her first grade, she got 80-plus for Chinese and 70-plus for math in the final exam.

When we went to the Ruijin Hospital again, the doctor was satisfied with my daughter's performance in the exams, saying, "Wow. That's not bad. Not bad!" That was based on my daughter's real situation. Since the doctor said her performance was "not bad", we thought she was not bad as a beginner, and that she would be better when she grew older.

Each piece of my daughter's bones was X-rayed and subject to X-chromosomal analysis, but we still didn't know the cause of her problem. My husband and I are just common people, while her problem resulted from the incident at her birth. The doctor kept encouraging us, "She will be fine. Her problem is not caused by congenital or genetic diseases." It's all because of his encouragement that we didn't give up.

Though I went far for work, I still needed to go back to my mother-in-law's after getting off. There were five people in the family, including my brother-inlaw. Only receiving a little allowance from my mother-in-law, I was the one who covered basically all the daily expenses and kept paying for everything. When my daughter was in the third grade, about 7 or 8 years old, my mother-in-law said, "Your brother-law will soon get married. Are you considering moving back to your own apartment?" Her words made sense, so, my daughter was transferred to another school in our district.

My mother-in-law lived in Yangpu District, but we had moved from Luwan to Hongkou District. The new school never considered student's previous performance, but required all transferred students to take an exam to see whether they could go up to the next grade or stay down. Shanghai schools used two kinds of textbooks, one was the $\mathrm{S}$ version and the other, $\mathrm{H}$ version. ${ }^{1}$ The former was simpler. My daughter used $\mathrm{S}$ at the previous school, but changed to $\mathrm{H}$ in the new school. After the test, she needed to repeat the third grade again. I couldn't tell the differences between the two versions of textbooks, but I thought it would do no harm to repeat a grade and lay a solid foundation. However, as the two versions of textbooks varied in difficulty, my daughter's academic performance became poor. The teachers weren't so nice, either. They didn't like slow kids. She struggled all the way up to the sixth grade. Every time when the school bell signaled end of class, my daughter would rush to the bathroom to avoid being bullied by her classmates.

Q: Didn't her teachers stop the bullies?

S's mother: The teachers didn't know, and she didn't dare to report. Once, she came home with swollen lips, telling us that a boy pushed her to the floor and kicked her. Her dad was mad at this. But he didn't handle it properly. He took my daughter

\footnotetext{
${ }^{1}$ In the mid-1980s, the state government allowed the adoption of one or several syllabuses, and several versions of textbooks in some disciplines in some regions. Shanghai published two versions of Chinese textbooks under the curriculum reform. One of them was the $\mathrm{H}$ version edited by the East China Normal University and the Education Bureau of Xuhui District, the other one was the $\mathrm{S}$ version edited by the Shanghai Petrochemical Complex and the Education Bureau of Zhabei District.
} 
to the class the next day, didn't contact the teacher in charge first, but directly went to the classroom and asked her to identify the boy who had kicked her. Soon as my daughter pointed at a boy, he kicked the boy hard at his bottom. Later, the teacher said to me, "Your husband shouldn't have kicked the boy. It'll be trouble with the kid's parents." I said, "Come on. My daughter has always been bullied. We cannot take more of it. But you are right, my husband shouldn't have kicked the boy. He should have contacted you to get in touch with the boy's parents to talk about this matter." Finally, the teacher called the boy to his office and told him, "Her parents were angry when they found out that you have been a bully and hurt her. Don't tell your parents about this, you know? Otherwise, when both parents start to fight, you won't be able to handle the consequences." The boy was frightened and we were not pestered anymore.

She struggled to graduate from primary school. Generally, these schools didn't issue graduation certificates. However, I went back to the school after some time, explaining my daughter's story. Others might not care about this certificate, but it meant a lot to us. Finally, the school issued a graduation certificate specially for her, with a seal on it. I was extremely happy about her graduation. The doctor at Ruijin Hospital was also glad to know this.

Q: Did she like any of her teachers in primary school?

S's mother: Her teachers were nice to her when she studied at the school affiliated to the railway system in the first, second, and third grade. When she transferred to the new school and repeated the third grade, due to her poor performance in exams and (odd) appearance, the teacher there didn't like her. The teacher told my daughter to her face, "You look so ugly. How come you don't look like your father and mother?" My daughter had grown up a bit. These words always made her feel inferior to others.

Her eyes also suffered from serious problems. She started wearing glasses even before going to school. Actually, the size of her both eyes were the same; the pupils and eye white were also of normal size, but they were not in the right position because of contamination by the amniotic fluid at birth. Her eyes had more white and her pupils were smaller. She also suffered from anorthopia and amblyopia. As I enjoyed $50 \%$ reimbursement of the medical expenses through the factory's insurance until she was 16 , we had been trying to cure her eyes during those years. Before reaching 16, the doctor said that she was able to accept the operation. So I took her to the Tongji Hospital for the surgery. It was painful. The doctor was actually quite considerate, since the operation wouldn't be possible nowadays due to its danger. He also advised, "We should try to avoid general anesthesia for kids like her", as he could tell that she was intellectually disabled and general anesthesia might harm her brain. But unfortunately, considering the optic nerve of kids could be very sensitive, we had to carry out general anesthesia eventually, and pulled the nerve to a specific position with a certain distance to the center, but not the exact center. This was because when my daughter grew up, the nerve would gradually come to the center, just like now. You can still tell a slight difference if you look carefully.

After that, I accidentally got pregnant again. My husband and I were determined that we didn't want another child. Our house was small, and we barely had any savings. My daughter also attended expensive afterschool classes. 
Q: Did she need extra classes?

S's mother: Of course! She had extra classes for math, Chinese and English.

Q: Did it work well to have extra classes?

S's mother: Just so-so. The teachers only wanted to make money, asking students to do exercises. Every day, my daughter couldn't finish her homework before midnight; we also tried to help her with the exercises. Though I still worked three shifts, I didn't even have any time to take a nap between the shifts, as I kept trying to figure out the answers to her exercises. From the first to the third grade, I could be of help. But after she went to middle school, it was indeed beyond our capability. Studying up to midnight, she tended to fall asleep, but we had to wake her up, urging her to finish the homework. Due to her precarious health, she couldn't afford to stay up like that. It was a vicious circle. She would faint when we took her outside on a hot day.

At night, I had to hold her in my arms when she slept, otherwise she would have had difficulty breathing. I stayed up late and went to work early in the morning. That explains my poor health now. Her teachers didn't know about her condition. They couldn't understand it, either.

Q: You mentioned that she couldn't finish her homework before midnight. What grade was she in?

S's mother: Since the third grade, when she was transferred to the new school. The new $\mathrm{H}$ version textbooks were harder for her. From the third grade to specialized secondary school, she always went to bed around midnight. Her dad stayed up with her.

Q: What about summer and winter vacation?

S's mother: She stayed at home alone. Her dad and I needed to work, and my office was far away. I asked her to do a certain amount of homework every day, but she always procrastinated. Sometimes, she encountered difficulties. She would just wait for us to do the homework with her after we were back and finished the housework. As her homework during summer and winter vacation was relatively easier, she didn't need to stay up late.

\section{A Kind Teacher in Middle School}

Q: Did she go to middle school in the district of her household registration?

S's mother: Yes. Her teachers in the middle school didn't like us. At that time, I didn't want to communicate with others, either. My daughter sat at the front of the classroom because of her poor eyesight. At a parent-teacher meeting, her teacher singled my daughter out, saying that she lagged far behind. I couldn't explain to the teacher, so I tried to flatter him. What else could I do? He couldn't understand it until one day he experienced it himself.

In the second year, there seemed to be quotas for students going up to the third grade, but the teacher wanted my daughter to stay down. I tried to persuade the teacher, "My daughter did lag behind, but we had tried our best, so did she. She studied until midnight every day and finished all the homework. There might be 
mistakes, but she really worked hard." The teacher didn't change his mind. Then I continued to beg him, "If possible, please just allow my daughter to go up. I don't think she will make much progress by repeating the second grade. I don't want much. Simply graduation will do." My words still didn't work. So, I stopped trying.

After that, it was decided that my daughter should repeat the second grade. Receiving the notice from the teacher who came to my home, I was really upset. I just blurted out, "We had no choice. You should be happy that it goes the way you wanted." I exactly said so. I didn't care about his feelings at all. He was the one who insisted on the grade retention and even brought the matter to the headmaster. The headmaster had sympathy for us, but he had to side with the teacher, who was the only teacher available for that class at the time.

So, we repeated the second grade. I was frustrated, but what could I do? Being afraid that she would be further despised in the new class, I told my husband on the first day of the new term, "Let's accompany her to the classroom. We can't leave her alone in the new class." We knocked on the door of the classroom, walked her in and told the teacher, "She has difficulties in learning. We don't expect the teachers to be strict with her, but we hope you won't despise her." The teacher assured us that she would be kind to my daughter, "Don't worry. I won't do that to anyone. They are like my own kids." We thought it was just an offhand remark, but anyway, that was all we could do for her.

When we needed to pay her tuition, I put the money in a bag for her. Being poor, we were careful with the money. But that was possibly not the case with other students. My daughter found a 100-yuan note and handed it over to her teacher, but the teacher failed to find the owner. In another case, students made the classroom messy at lunch. My daughter found a broom and cleaned the mess away. The teacher saw it. But she didn't tell us about the two stories.

Once, the teacher asked parents to go to school to collect a transcript, but my daughter didn't tell us. At that time, I was on leave at home after surgery for a hysteromyoma excision, and her dad had to go to work (sobbing for $1 \mathrm{~min}$ ). When I was in the hospital, she asked my elder sister to take me a note written by her, which read, 'Don't worry, Mom. You'll be fine. I have prayed for you. You will come home safe and sound."

Then the teacher called while I rested at home. I told the teacher, "I didn't know. I will go to school right away." I went there with my hands holding my belly. The teacher used to blame us whenever we went to her office, but this time, as soon as I arrived there, I said, "I was on leave, but my daughter didn't tell me about this notice. I didn't know." Seeing my hands over my belly, the teacher asked, "Are you OK?" I answered, "I was recently discharged from the hospital after surgery. I'm having a rest at home." She gave me a seat and told me, "Don't blame your daughter. She has been good. I asked you to come to let you know that she has made great progress." The teacher who insisted on grade repetition was also in the same office. All the other teachers disapproved of what he had done to my daughter. Then the current teacher told me how my daughter handed over the money she found to the teacher, and how she cleaned the classroom and praised her. The teacher in charge taught Chinese and my daughter was good at Chinese. The teacher said, "Now your 
daughter often comes to talk to me. She also goes to read in the library. After the students were divided into groups for English class, her English improved a lot." I wondered how all these things happened, but I said, "I am glad to learn that she has made progress."

Thanks to the new teacher, my daughter became livelier and continued to make progress in her studies. This teacher came to Shanghai from northeast China. Later, she underwent the same surgery that I had, and stayed in the hospital just across the street. Learning that her classmates were going to visit the teacher, my daughter wanted to join them, but was refused. So she followed them secretly to the hospital and found out the teacher's ward. Knowing that I had the same surgery, she told me, "Mom, my teacher is in the hospital. The same surgery as yours." She asked me to visit the teacher with her. I agreed and prepared a dove soup. I explained the process to the teacher, who was moved to tears. The teacher said, "I know she works hard, though she doesn't make much progress. But I never expected that she would come to visit me." The teacher probably criticized her classmates and praised her as caring and considerate. After that, her classmates began to play with her.

After she graduated from middle school, considering that she had difficulty in learning but worked hard, her teacher suggested that she didn't need to take the college entrance exam. The teacher was kind to advise us, "You may consider specialized secondary schools. They are more suitable and affordable. She can study e-commerce and become a cashier after graduation. This kind of job is needed everywhere without fierce competition. Also, there's no limit on age. She can do it for a long time." Following this advice, we mainly considered such schools and my daughter was later admitted to one.

Her middle school was not famous. As my daughter was considered a poor student, the headmaster thought her admission to a specialized secondary school was worth publicity. He asked us to share our experience of education, based on which a blackboard bulletin would be prepared. As my neighbors' kids went to the same middle school, I didn't want them to know about my daughter's real situation. So, I declined the request, "I don't want to discuss it in public. No matter whether her study performance is good or bad, it's our own business." Then the headmaster didn't insist. Anyway, she had graduated. We should be optimistic.

Q: How did you help her when she prepared for the entrance exam of the specialized secondary school?

S's mother: We learned the same books with her. If she had any problems, we would check the books to work it out and then teach her, or consult others, like the senior students or her classmates living nearby. After we understood the answer, we would teach her again and again. She worked hard. We also did a good job cooperating with her teacher. We all made a lot of effort. The teacher said, "You've done a nice job." I told her, "Yeah, we never watch TV at home. We are afraid that it may distract her. Let's work together to improve her performance."

Q: Did she take any IQ tests during the period from elementary school to middle school?

S's mother: I took her for this test secretly when she was in middle school. The scores were graded as low, medium, and high. Her score was between 60 and 70, 
"high" among kids with intellectual disability, but "low" among kids without disability. If the score was really poor, I probably would have bowed to the inevitable. But it was just because her score still showed a glimmer of hope that I didn't give up on her. However, we didn't want others to know the test result.

$\mathrm{Q}:$ Do you accept the result?

S's mother: Basically yes. The test was very strict.

\section{Admitted to the CYL at a Specialized Secondary School}

S's mother: Her teachers at the specialized secondary school were kind to her, too. Though all the other classmates weren't slow, they just didn't devote themselves to studying. Under such circumstances, my daughter still worked hard. The teachers thought highly of her. She handed in homework every day, despite possible mistakes. I thought her performance was gradually improving.

She was admitted to the Communist Youth League (CYL) at that time. It was not easy, but she finally made it. We had this tradition in my home. Apart from my mother, a CPC member, there are still many CPC members in my extended family. I didn't get the chance to apply for membership since I often asked for leave to take care of my daughter, but I believed that she should try everything that normal kids did. We were admitted to the CYL when we were students, so I thought it would be nice if she could join the CYL at the same stage. Whatever the result, I would accept it. I asked her, "Did you apply for admission to the CYL? I think you can make it. Anyway, you should give it a try." Later, the teacher noticed that she worked hard and took her task of cleaning the classroom seriously, so, they made an exception and admitted her to the CYL. She was glad.

An incident happened concerning this admission. There was a review meeting before she was admitted to the CYL, where others would comment on whether she could be admitted. It was normal that people would have different opinions and unfavorable remarks. But my daughter couldn't stand it. I could have prepared her, but I didn't know the review meeting for her would be held on that day.

My daughter is ill-tempered. After the review meeting, she held her anger in for a long time, until she cut her wrist after returning to the classroom. You can still see the scar now. She could have killed herself. But luckily, the wound was not deep. Her teacher noticed the wound and sent her home after treatment at the clinic.

After I went home from work, she cried as soon as she saw me. I was also sad, but I didn't stop her. When she stopped crying, I asked her to explain and I analyzed the situation for her, "You are simply too vulnerable. Today's meeting is completely normal and inevitable. You are admitted to the CYL, but you haven't met the requirements. More effort is still needed. You may encounter much trouble in your future. So, you must have a strong mind. You've gone through a lot since childhood. Sometimes, we just can't control everything. You should be prepared. How could you hurt yourself? Now, you feel pain and you think it's ugly." Whenever my daughter had difficulties, I had to spend a lot of time and effort to talk with her till 
she could understand it. Regarding the review meeting, ultimately, she could make sense of it.

This school was actually good. When she was admitted, the teachers wouldn't think of the accident at her birth. Maybe the teacher was doubtful, but we told the teacher she was just in poor health. People of poor constitution are generally not so energetic. So, her teacher only knew she was weak.

At that time, I was quite strict with my daughter. If she didn't finish the homework that I assigned her, I would spank her when I got home. Looking back, I think I shouldn't have done that to her. Such pressure would only affect her health, but I wasn't aware of this back then. Being young and inexperienced, I just felt upset to see my child like this, when others have normal kids. I was just too reckless.

\section{Working Diligently at the Supermarket}

S's mother: After 2 years of study at the specialized secondary school, all the students started their internship at a supermarket in Pudong. It was far from our home and she needed to take two bus routes. Back then, there was no bus going from Pudong to the downtown area of Shanghai after $10 \mathrm{pm}$. There was no bus to take her back if she worked the day shift and no bus to take her there if she worked an early shift.

So, she took an internship at a nearby supermarket, upon the recommendation of a friend. It was hard work. My daughter didn't know how to get along with her colleagues, most of whom were of my age. She also tended not to talk about her experience at work. The supermarket didn't let her go after the end of her internship, nor did they sign a contract with her. She kept working there without any pension, housing fund, or medical insurance, until she was formally employed after an examination by the authorities.

She was still willing to learn more back then. She didn't go to high school, but she still wanted to learn after graduation. She said, "Even though I won't sit in the college entrance exam, I want to learn something." She wanted to keep studying while working. In the supermarket, foreign customers came often, but they seemed to have difficulties in communicating in Chinese. Seeing this, she thought English was a necessary skill. She decided to learn this at the foreign language school near her workplace. She passed by it every day on the bus. She said, "I'll learn some basic English."

I supported her totally. Young people should learn as much as possible. So I enrolled her in a basic English class at the nearby foreign language school. My salary then was about 800 or 900 yuan a month; the tuition fee would cost more than 800 yuan. She went to the school twice each week, once on Saturday and once on a weekday. At that time, she could take a day off on weekends. But the manager probably didn't like her. My daughter had only had a few lessons when the manager came to tell her, "Why not ask for leave on a weekday and leave the weekend session to people with kids? They need to take care of their children." I replied, "My daughter has just signed up for this and paid over 800 yuan. We wouldn't have done so if you 
had raised such a requirement earlier." The manager said, "We had no choice. Other people have to take care of their children." Later, my daughter said, "Never mind. I'll quit."

My daughter's job was tiring. When she worked the day shift, she needed to move the shelves around. If she worked the day shift, she would not be able to come home before midnight. If she had to tidy up the workplace after the customers left, she could not get off until early morning, like 3 or $4 \mathrm{am}$. In the beginning, she could still take some rest and even lie down for a while and come home the next morning by bus. Later, their shifts became a mess. People working the noon shift were required to take stock after getting off and continue to work the next day. On those occasions, she had to start working again at 9 or $10 \mathrm{am}$.

Q: So, she didn't have time to sleep, right?

S's mother: I told her to take a taxi to return home and sleep for a while after getting off at 3 or $4 \mathrm{am}$. Due to her poor constitution, she often had a fever. Once, she didn't feel well at midnight, so I took her to a hospital for an IV infusion. Her body temperature was over $39{ }^{\circ} \mathrm{C}$, which required 3 days of leave, but the supermarket allowed only 1 day off. At that time, few young people would work in a supermarket.

She started in the supermarket as a cashier, handling over 10,000 yuan every day. Once, a middle-aged woman paid for part of the things, and went back to weigh one item that wasn't weighed. She told my daughter the paid items were left at the cashier, but they were nowhere to be found when she came back. She asked my daughter, "Where are my things?" My daughter said, "I have no idea. Maybe somebody took them away." There was no video surveillance at that time. The woman asked my daughter for compensation. Facing this, my daughter reported to her supervisor and checked the receipt at the cashier register. The things were indeed paid, but disappeared. I don't know how they dealt with the situation ultimately.

Afterwards, my daughter was transferred to another job in the underwear department as a tally clerk. When customers asked for a return, her colleagues of my age would tell her to deal with it. But how was my daughter able to handle this? She wasn't good at communication at all. She was cursed by customers, but she didn't tell me until later.

Q: Did she make friends with any of her colleagues at the supermarket?

S's mother: She was close to some of her colleagues. But they didn't work in the same department.

Q: Were there any good friends among colleagues in the same department?

S's mother: When her supervisor got married, I told her to give her 500 yuan as gift money, even though her salary was merely 800 yuan. The effort was in vain. Ever since she was little, we kept giving gifts to her teachers and other people. Even a new cotton sweater that we treasured a lot was given to others as a gift.

$\mathrm{Q}:$ Were her teachers kind to her after receiving your gifts?

S's mother: Unfortunately...Perhaps it could have been worse if we hadn't done so. I'd rather suffer myself than see her suffer. We didn't have much savings as well. Our life was indeed hard. 
By 2007 or 2008, due to the financial crisis, the supermarket sent her home before the expiration of the contract and asked her to submit a resignation letter. My simple daughter just did what they said, totally unaware of their trick. If the supermarket would have given my daughter the worker's record immediately, she could still have explored other job opportunities. But it didn't. The staff couldn't even state clearly where the documents were kept, either in the head office or in the supermarket itself. My daughter made many trips in vain.

I was angry when my daughter told me about this. She could have worked there till the end of the year. How could they ask her to leave suddenly? Not knowing about the resignation letter, I went to the supermarket to seek explanation. They told me, "Your daughter wrote the resignation letter herself." I was astonished, "She wrote it under what circumstances?" They started to make excuses. Then I blurted out, "Do you know my daughter's condition? Do you know what happened at her birth? We didn't tell you about her story, simply because we don't want you to despise her! We are all parents. We all have children to care about. Would you allow such things to happen to your child?"

Then I read the articles of the Labor Law. According to its rules, if my daughter was unqualified, she should be entitled to the training provided by the supermarket and shall be only fired when she reaches the requirement of a new job after the training. So, I asked the supermarket, "Did you train her? How can you fire her like that without any proper measures?" What's more, she only received her salary of that month. I complained, "You can't do this to her. My daughter is a special kid. Your decision is completely unfair. Why would you fire my hard-working daughter but keep the careless ones? What's wrong with your policies?" The manager said, "All the formalities have been completed. What can I do?" I told him, "It's your business. Now you know about my daughter's situation, just do as you think fit. She did a nice job here. She liked her job." The manager continued to make excuses. I got mad, "Anyway, you shouldn't have kicked her out all of a sudden and asked her to submit a resignation letter. My daughter needs a custodian to make decisions for her. Did you contact us? What's worse, simply because you didn't give her a worker's record in time, she can't be hired in other supermarkets. She lost her source of income since the day you fired her. She has made many trips in vain to obtain her record. Will you cover her travel expenses?" I asked for 3 months of salary as compensation, but the manager required that we pay the tax. This was totally insane. I yelled, "Oh my god, it doesn't make sense at all. You force us to take the lump-sum payment. How dare you deduct the tax!' Finally, we didn't pay tax for the money we received.

$\mathrm{Q}$ : Can you remember when she received her first salary?

S's mother: She received several hundred yuan during her internship. I have always considered my daughter as a normal kid. Though my colleagues advised that I should tell her to hand in the money and teach her to save it and spend it wisely, I didn't follow it exactly. I just told my daughter, "Now you have your own salary. I don't want any of it, but you should save 100 yuan for your dad and buy some gifts. He has done so much for you. When you were in the hospital, he stayed there to keep you company day and night." At that time, there was a downturn in the textile factory, so 
I found a new job at the Oriental Pearl Tower and her dad became a taxi driver. Our life was hard.

She received 300 yuan for her internship. I remembered she probably spent 50 yuan and bought a box of cigarettes for her dad. Later, she started working and received her first salary of around 900 yuan. Considering that her dad was taking supplements of Only, I told her, "How about buying Only supplements for your dad every month? It costs more than 100 yuan." She agreed. She's really grateful. I told her that I didn't need her money. "You can keep it to cover your daily expenses and save the rest of it."

I told her to open a deposit account when she still earned 300 yuan a month, but she didn't agree. She asked, "Why? All the students have money in their wallets, except me. I envy them a lot every time I saw them shopping, but I didn't have any money with me. Our family is poor as well." I told her, "You can save as much as you like. If you can save 50 yuan this month, I will give you another 50 yuan. That way, you will save 100 yuan." She couldn't come around, but told me she would save 20 yuan, so I said you could get 20 from me as well. Later in the first month, she probably saved 50 yuan, so, I gave her another 50 and we put the 100 yuan in her account. Gradually, she understood the mechanism. She would tell me, "Mom, I have enough pocket money this month, I'll save all the rest in my account." I said, "Fine. You have saved 300 yuan, then I'll give you 300 yuan. You can put it all in your account." That's how I encouraged her to save money. When she was at school, I gave her 1 yuan every day as her allowance and some more to buy bus tickets. As she grew older, she was in charge of her allowance.

Now, she receives a monthly salary from the factory. I put the money in a term deposit account for her. She already sets her own savings goals. This makes her confident and happy.

She understands that my husband and I are working to support her. Actually, we are not that poor, but I want to make her aware of large expenses in the family so that she can also contribute. I would tell her, "We are a bit stretched this month. I spent a lot buying gifts. Can you help us?" She would offer to give me some money, and said, "No problem, Mom. Here is 100 yuan for you." That's already a lot for her. I don't need it actually, it's just that she should be aware of the responsibility.

$\mathrm{Q}$ : Is she willing to give you money?

S's mother: Yes. She also bought food as gifts for me. On my birthday, she bought me a small birthday cake. In fact, she herself wanted to eat the cakes (laughing). It's fine. Some kids do not know how to manage their money.

Q: Does she buy you gifts on holidays like Mother's Day?

S's mother: Yes. She is grateful. When she was at the specialized secondary school, I gave her 1 yuan per day as pocket money, but she would save it and buy me gifts on Women's Day.

Q: What did she buy?

S's mother: Like a small cake, maybe several yuan, or a card holder. Different small objects. 
Q: Do you like them?

S's mother: I do, even if they don't appeal to me. I don't care about the price, but her affection and gratefulness. I need to prepare her for many things. For example, she should get prepared if we pass away some day. I often ask her, "How are you going to live on your own?" When she answers, I give her some advice. "Who can you ask for help if you have difficulties?" "The neighborhood committee and similar organizations." She knows a lot.

\section{Applying for the Disability Certificate in Desperation}

\section{Q: Why did she stop working later?}

S's mother: Previously, as my daughter still wanted to work, we went to the employment agency of the neighborhood committee for help. The staff there were very nice. There are eight major supermarkets in Shanghai, but young people here don't like tiring or poorly paid jobs, including in the supermarket. My daughter, however, was willing to work hard in these places.

A staff member in the agency offered to help us, but he was confused after my daughter failed all the interviews with supermarkets. He said, "How could this be? Her major fits the job perfectly." Then he recommended another supermarket. "The person in charge of the interview is my friend. You can have a try. I'll see where the problem lies." She failed again.

You can't even imagine what the interviewer said. He told us, "This girl is oddlooking. She can't work here." At that time, my daughter still suffered from a slight squint. With a strong sense of inferiority, she never looked at people directly in the eye, but like this (lowering her head while raising her eyes). Before she had the eye surgery, others often said that she was rolling her eyes. She couldn't control it, nor could she explain it to anyone. The interviewer was just blunt to say so. It was mean. You're hiring staff, but not supermodels, after all.

Before that, I never thought about applying for the disability certificate. At the neighborhood committee, the director asked my husband, "Why would your daughter stick to this struggle among ordinary people? Do you feel hopeless?" My husband and I didn't want to acknowledge that my daughter had an intellectual disability, but the people there could tell. They were deeply moved, "You can't solve the issue of your daughter alone, but you still try your best to find a job for her. We think you should turn to the government for help."

It was a hot day. The temperature was about 37 or $38^{\circ}$. My surgery wound was itchy after accompanying her to so many interviews. My job wasn't that tiring, allowing me to spare some effort on her. Now that the neighborhood committee advised us to apply for a disability certificate, we thought it might work, but we were not sure.

Q: How did she obtain the disability certificate?

S's mother: If she hadn't lost her job at the supermarket, we wouldn't have applied for it. This was our last resort. The formalities were complicated. First, we had to submit applications and other required documents to the subdistrict. They had an 
office dedicated to services for the disabled. We applied in 2009. It was already very strict at that time, because people with disability certificates can receive an allowance.

At birth, my daughter was discharged from the hospital a month later than me. I kept all her medical records and her photos we took since her childhood. A lot of documents were handed in. Everyone said it was difficult to obtain the certificate. I said, "I have no other way out. In addition, as she grows older, so do we. We won't have enough energy." Later, the clerk said they would submit the documents to the relevant administration. We lived in the Hongkou District. Perhaps there was a fixed day for subdistricts to submit documents.

After a long period, we received a notice for a physical examination and went to the mental health center of Hongkou District for a test. The doctor read the medical record and asked us some questions. Then, my daughter was taken to a room next door for an IQ test. It was very rigorous. My daughter was required to build an item with blocks within several minutes or solve a problem. She thought it was too difficult to solve, while the doctor was patient and explained the question to my daughter in great detail. Anyway, the doctor tried to help her with the problems, so that she could proceed with the test. However, sometimes, my daughter was still unable to work out the answer. She was probably nervous and scared because of the doctor's attitude or language. When she saw me after finishing the test, she burst into tears. I asked what was wrong, and she said, "I couldn't work out the answer. The doctor forced me and scared me." She was perhaps too nervous to answer the questions. The doctor had a procedure. After the IQ test, she had an EEG scan, the results of which were not good. The doctors then spent some time in discussion after the IQ test and EEG scan before they spoke to us. According to the results, my daughter had moderate intellectual disability.

I was simply confused. I didn't think her intellectual problem was so serious. Anyway, we had to face the fact. What could we do? If the disability certificate was issued, it would be even harder for us to find her a job. Considering her poor health and that she was often bullied in her workplace, I asked others about information in this regard. I learned that persons with moderate intellectual disability could apply for an allowance for the severely disabled and unemployed. I thought that was the only choice. Initially, her monthly allowance was only a bit more than 400 yuan, but it gradually increased every year thanks to the efforts of the government.

Q: How did she obtain the allowance for the severely disabled and unemployed?

S's mother: The application was made through the subdistrict. I have forgotten the specific formalities, but I remember that we submitted the application after receiving the report of moderate intellectual disability. With the allowance, she didn't work any longer. On one hand, I was concerned with her health. On the other hand, she had suffered from her tiring job in the previous 3 or 4 years. People of the subdistrict said I had been too harsh, "How could you allow your daughter to compete with kids without disabilities? Have you ever considered that it may have had a negative effect on her personality and mentality?" It still scares me. At that time, she could have received an allowance as severely disabled and unemployed, but persons with mild disability could not. Now, all persons with disabilities have an allowance. 


\section{Being A Monitor at the Sunshine Home}

\section{Q: How did she come to the Sunshine Home later?}

S's mother: After the disability certificate was issued, she stayed at home all the time. Once, I went to the subdistrict office. A woman there was very nice. She was concerned with my daughter, and asked, "How's your daughter now?" "She stays at home every day." "What a pity! We have a Sunshine Home here. It is very good."

I knew about the organization. However, just as I didn't want to enroll her in a special kindergarten when she was little, I didn't want her to go to the Sunshine Home. People say that one can be improved by spending time together with smart people. What would become of her if she went there? But... anyway, I couldn't make up my mind.

While I hesitated, the woman said, "How about I show you around?" I thought it was a good idea. So, she took me to visit the Sunshine Home. The teachers in the office showed me many videos on their computers, which showed that the students here made great progress in a year. I was deeply impressed. How could the teachers transform the students in the classroom to the kids shown in the video? I couldn't believe my eyes. I told them immediately, "I'll discuss it with my daughter. If she wants to come, I won't object. If not, there's nothing I can do."

My daughter resisted it. "I won't go there," she said. But I was worried about her future if she stayed at home all the time. So, I tried to persuade her, "Just go and have a look. You don't have to stay. Think of it as an interview."

The next day, I took her to the Sunshine Home. We visited the classrooms and teacher's office. The teachers showed us some documents on their computers. When she walked out of the office, she was surrounded by many students, who were friendly to her. They were all simple-minded. She seemed to be included into the group of kids very quickly, which was beyond my expectations. She was happy to be there. The Sunshine Home wasn't open to every kid with ID in the subdistrict.

Q: Does she need to satisfy some requirements to be admitted to the Sunshine Home?

S's mother: Some people may not want their kids to come here, especially kids with problems. The parents are afraid that the kids won't be able to have access to motivated people, and gradually become worse. But if they knew about classes here, they would change their minds. At the Sunshine Home, students go on outings in spring and fall. They have summer camps as well. An annual physical examination is provided by the government. Now they have full schedules. They have art lessons lectured by a retired teacher free of charge. Watercolor tools are offered as well. The dancing teacher is also a volunteer. I think the Sunshine Home is well organized.

Let me show you some photos (showing photos of her daughter as a small child). The teachers didn't believe this was my daughter. These are taken recently (showing photos of her daughter now). First, she is smiling in every photo. In the past, she was shy. If we came across somebody in the street, she would immediately hide behind me. After coming to the Sunshine Home, she became much more confident. Second, her health is improving. These are photos I took when we went swimming 
and traveling (showing photos on her mobile phone). I want to take my daughter to travel as long as I am capable. She doesn't have any friends. My relatives are not reliable. So, I can only count on myself. I have decided that I will give my poor daughter whatever she wants as long as I can afford it. This is a photo of them in a dancing competition. My daughter is a monitor at the Sunshine Home.

Q: What does she do?

S's mother: Nothing special, except for announcing the beginning of class and reporting to teachers in case of any problems.

Q: What lessons do they have at the Sunshine Home?

S's mother: Painting, music, and dancing. Also, as half of the students here have mental problems, a doctor here lectures on medicine and mental health. These kids know about a healthy diet and how to take care of themselves now.

The Sunshine Home is really good. Without it, these kids would have no place to go. They are pure and simple. Compared to them, my daughter knows how to use money wisely. That's the benefit of going to school. My daughter is weak in health, but she is better in other aspects. The other kids here didn't go to school, but they have stronger bodies. Every coin has two sides. Sometimes, I feel regretful that my daughter didn't receive further education, but on a second thought, health was more important. For kids who know nothing about money, their parents are worried. They don't make efforts to push their kids into the society like we do.

Q: What makes you think your daughter is more confident and optimistic?

S's mother: She was always on tenterhooks when she worked at the supermarket, because others bullied her. At the Sunshine Home, she seems very relaxed. In the beginning, they didn't have many activities. They did radio gymnastics exercises in the morning, then the teachers would talk about the news of the day, just everything they deemed fit. There were no fixed lessons. The classroom is also very good with inspiring banners, "If you can do it, then I can do it." The teachers here are very patient. Over time, she adapted to this place.

They have a summer camp every year. My daughter not only drafted the opening and closing remarks, but also acted as the hostess. When her teachers told me about this, I couldn't believe my ears. Afterwards, they had a Spring Festival get-together, at which my daughter and another girl were hostesses. Their performance was excellent. I was amazed! The Sunshine Home considers the characteristics of every student and allows them to give full play to their strengths.

Q: Develop the strength based on their characteristics?

S's mother: Yes. They can do what they are skillful at. My daughter is not very handy and doesn't know how to string beads. This actually requires certain skills, right? Another girl close to her is just very good at it. Not long ago, their teacher bought some knitting wool from an online store. There were knots in the wool. She has finished two pieces and is now working on the third piece. I am impressed with her teacher's skills. It seems easy for the teacher to teach them knitting.

Q: Does she take her work home?

S's mother: Recently, she brought home a papercutting. It was the Chinese character "Fu" (meaning happiness). She is not the best among her classmates, but I'm happy that she can make these things. Anyway, I don't know how to cut the paper 
(laughing). The Sunshine Home organized various activities. Once, she brought home a picture frame with a photo inside. I can't figure out how it was made. Sometimes, she has brought home a potted plant. Anyway, she often brings her new works home.

Q: What do they do in the art and music classes at the Sunshine Home?

S's mother: I can't remember what she painted recently. Anyway, she has been painting. Portrait, still life, animals. They have different subjects.

Q: Does she use gouache or watercolors?

S's mother: I think it's the latter. I once went to buy the material with her. Initially, she messed with the watercolors and used them up very quickly, so, I had to buy her a new set. Then, she gradually mastered the techniques. Her paintings now are not bad. I am amazed that she could make such great progress with the guidance of her teacher.

One of her classmates, the son of their dancing teacher, is illiterate, because he didn't go to school. Once, at a get-together, maybe the Spring Festival party, he was asked to write "I love my mom" (in Chinese) on the blackboard. He did a nice job. At the sight, his mother burst into tears as the boy had never written a single character. We were deeply touched by his writing on the blackboard. These kids must have made great efforts to achieve such progress.

Q: Do they have other activities at the Sunshine Home?

S's mother: They learn dancing. It takes a long period for them to learn a dance, because they have to learn over and again. You saw it when you came here last time. The teacher soon gets tired. Each student does the move differently, and they have to be corrected one by one. It's really hard for them. When they command one dance, they will proceed to the next. If they are going to the nursing homes or other places to participate in charity performances, they'll practice the old dance again. Previously, she couldn't dance at all, because her limb movements were uncoordinated. The teachers must have made a tremendous effort to teach the students. It's amazing.

Q: After she was enrolled in the Sunshine Home, did she go to work?

S's mother: Due to her registered status as seriously disabled and unemployed, the Sunshine Home could not recommend any job. Otherwise, she could seek employment after receiving training here.

Q: Can you still remember her participation in the Talent Show for Sunshine Homes?

S's mother: After learning about the talent show, the teachers of the Sunshine Home chose several students, including my daughter, to practice dancing every day. Later, they went to the talent show several times. There were at least two costumes. In the first round, she wore a pink, shiny long-sleeve top, a skirt like yours, and white sneakers. She looked pretty. They competed over and again, and it got increasingly hot. So, when the competition was approaching the final round, she had a new costume: a blue and red striped short-sleeve T-shirt, white sports pants, and white sneakers. They really wanted to make it to the final round, but they were eliminated in the second-last round. Seeing the depressed students, the teachers and parents comforted them, "You have done a good job. It's not easy." Contestants from other subdistricts were also great. 
Q: Was the competition fierce?

S's mother: Very fierce. The contestants were all excellent. A little boy played the saxophone very well. It was quite impressive.

\section{Improved Health Thanks to Special Olympics}

Q: Did your daughter participate in Special Olympics?

S's mother: Yes. She competed in Special Olympics twice after she was enrolled at the Sunshine Home. Special Olympics is not held annually. It is held after the Olympic Games.

Q: Did she compete in events of different levels, like in the subdistrict, municipal, and international ones?

S's mother: No international ones. I'm not sure about municipal level, either. But I know that she participated in Special Olympics for the subdistrict. She also participated in a Special Olympics competition held by the Disabled Persons' Federation of our district.

Q: Can you remember the details?

S's mother: She was involved in a variety of activities. She was a member of the waist drum team of the District Disabled Person's Federation. She could play the waist drum and flat drum. She also participated in performances, in addition to training in her spare time. They have a lot of activities relating to Special Olympics, like table tennis, dancing, and singing.

$\mathrm{Q}$ : Did she win any medals?

S's mother: She won several award certificates, but maybe no medals. She was once the third in a competition and was granted a little award certificate.

Q: What's her specialty among the Special Olympics activities?

S's mother: She always had a passion for singing, but the other skills are newly acquired.

Q: What about table tennis and other sports events in Special Olympics?

S's mother: She likes calligraphy, but there is no calligraphy competition in Special Olympics. There are only sports. She competed in many sports games, like table tennis, jumping rope, carrying a basket and throwing balls, things like that. Her health was not bad in those days, so she could go to the District Disabled Persons' Federation every Saturday and Sunday for half a day each time and participate in such sports activities. But later, as her health became poor, she didn't go there very often.

However, my daughter and her classmates all participated in the Special Olympics activities. A major benefit is that their health is much better. Their physical coordination and hands-on abilities have also improved. They can compete in simple sports activities like table tennis. The government is kind to them and offers each participant some awards. This makes them very happy. Some of the participants are strong competitors. A girl from the Sunshine Home is one of the Special Olympics youth leaders. 


\section{Relatives Unable to Accept the Situation}

Q: Did you conceal her intellectual disability from your relatives and friends?

S's mother: Not from my siblings, because I couldn't have. It reminds me of a story. Once, my mother-in-law had a fever and didn't feel well. She stayed in bed and told my daughter, "Sweetie, can you play by yourself? I need to rest." My daughter was playing with toy blocks. She looked at her grandma, and perhaps she thought she should take care of her grandma. So, she dipped a towel in cold water, and asked her grandma to put it on her forehead. Her grandma likes her, so do our other relatives. My mother-in-law told me about this after I got home from work. She was moved to tears, saying that my daughter was a good girl and that we should be nice to her. As for my colleagues and friends.... I didn't talk much with others at that time.

$\mathrm{Q}$ : Is that because of your daughter?

S's mother: (Nodding). We got together with our friends on holidays. They often asked, "How did your daughter go in her exam?" My daughter would immediately hide in the bathroom, to avoid being asked. I understood her. So, I would say, "Don't mention it. My daughter is hiding away again." Then, they would drop the topic.

I don't like it when people talk about their children dating or getting married. But there's nothing I can do. My daughter suffers, because we tend to be mad at her when we are upset. When she was little, we spanked her and sometimes scolded her, "Why are you such a dumb head? Why couldn't you be smart like other kids?" Now, I also tell my daughter, "You have to grow up. I am getting old, and someday, I won't be able to help you. How are you going to take care of yourself?" I worry about her future so much.

Q: How do your friends and colleagues view her?

S's mother: People gossiped. When she was little, people would point at her and show a weird look when I took her from the kindergarten to take a shower in the bathhouse of the factory. What could I say?

Q: Do your friends also gossip about her?

S's mother: They don't. You know my daughter's situation now. They also know her situation, so, they don't gossip about her. But we can't afford to tell everyone about her disability.

Q: Do you speak your mind to your friends? Do they encourage you or try to comfort you?

S's mother: Well...Suppose you are my friend. You know my daughter has an intellectual disability, but have no idea of my life with my daughter. Therefore, you won't focus on my daughter. In most cases, I just listen to them talking about their kids. When you don't have a child who has been ill since birth, you can't understand my hardship. I have a very good friend living across from my house before we were married. We were really close back then, but we rarely met each other after we both started a family, even when I went back to my mother's home. Decades later, we suddenly encountered each other in the street and have got in contact. She knew my daughter was intellectually disabled, but she didn't know the details. She said that my personality has changed a lot. According to her, I never acknowledged 
defeat, but now I am mentally strong, and talk less. She said I was like a different person. I wasn't afraid to try things before I got married, because I would bear the consequences alone. Now I need to think about things more. I have learned to take things easy.

Q: Has your daughter brought about a lot of changes in you?

S's mother: Too many changes. To be frank, my husband and I had been classmates for 6 years before we got married, we once had deep affection for each other. But we often quarreled. I can tell that he has grievances. Now, he is a chauffeur at a company. It's natural that he feels upset to think of his daughter, while the other young girls at the company are clever. We both have grievances. Who is to blame? I told my husband, "There is nobody to blame. You can't blame me, because I didn't understand the situation when she was born. You can't blame our daughter, or she'll be sad. I want to blame you, because you could have refused the emergency treatment. But you didn't understand the situation, either." My mother was also at the hospital when my daughter was born, but she didn't say anything since my husband didn't refuse the emergency treatment. Anyway, everyone is upset. Sometimes, we quarreled over trivial incidents because of different opinions. We are not happy together. Had it not been for my daughter, we probably would have divorced a long time ago.

Sometimes, other kids' mothers talked about our marriage. It is natural that husband and wife may have different opinions. In any case, I had to take good care of my daughter. I had to. Now I am getting old, and my health is not very good. My daughter is gradually better than before. So, for many things, I just don't take them to heart. My husband is ill-tempered. He is a dotard, I mean it.

Parents of kids like my daughter have been suffering. We suffer a lot. We do not have the heart to think about the future. My daughter has a classmate, whose father often came to the Sunshine Home. In the past, it was his mother who often visited here. His mother suffered from heart disease, high blood pressure, and osteonecrosis and had several operations. She's a procurement agent and makes a lot of money from her work. Thus, his dad is responsible for housework. Old people usually have difficulty in sleeping. Once, when the father couldn't sleep at midnight, he cried at the thought of his sick wife and son with ID. Parents of such kids are usually not cheerful. But we must perk up.

Q: You mentioned that your husband accompanied your daughter to the hospital when she was little. Wasn't he nice to your daughter?

S's mother: He is indeed nice to our daughter. At the beginning, we both went to the hospital and spent much time waiting, so we had no time to eat. Over time, we learned from experience and took turns to stay at the hospital and do household chores at home. That way, we could have dinner ready when either one got home. At that time, it was impossible for us to keep dining outside. When I got pregnant again, both of us were determined that we didn't want another child. My husband was considerate. I had an abortion and continued to focus on my daughter. When my mother-in-law learned about this, she said, "Why did you have an abortion? It might have been a boy." I told her, "If we had a second child, what would we do with the elder one? We don't even have enough energy to take care of her." My mother-in-law 
said, "She can stay with me. I will treat her like my own daughter and teach her how to live." I don't think she could teach my daughter as well as we do.

Q: Do you and your husband fight less now?

S's mother: Well, as a menopausal woman, I still quarrel with him sometimes. The key factor is that I don't want to fight with him.

Q: Do you fight less over your daughter?

S's mother: She's still the main reason why we quarrel. My husband couldn't help comparing her to other kids, and I would refute. Once, he told my daughter, "You deprived me of my right to be a grandfather." Hearing this, my daughter looked at me. I thought his remarks were too much for her, so I argued against him, "How could you say something like that? People may get married, but many couples don't have kids. How did she deprive you of your right to be a grandfather? If you want a grandchild, go and adopt one from the orphanage and have him or her call you Grandpa!' Now, I just don't want to quarrel with him. My heart can't bear it. I don't mind whatever he is doing, as long as it is not excessively unacceptable, and his money is brought home.

\section{Yearning for a Carefree Future}

Q: Does your daughter receive any support from the government?

S's mother: My daughter receives an allowance from the government every month, which increased from over 400 yuan to 1,150 yuan. She also receives another 480 yuan for monthly nursing fees for the seriously disabled and unemployed. Altogether, she receives about 1,600 yuan per month now. As my husband and I have this only child with ID, we can receive 400 yuan respectively from the government every month, increased from about 80 yuan initially. Then that's a total of 800 yuan every month. It has not been a long time since we first received the allowances, because my daughter didn't apply for the certificate until in recent years.

Q: Do you give her any advice when she has difficulties?

S's mother: My husband was previously a taxi driver and had rich experience dealing with various people. We talked about this over dinner. I also shared my experience in dealing with difficulties with her. So, she made it a habit to talk with me whenever she encountered any difficulties at the Sunshine Home. There was only one time she didn't tell me. While the students were taking a nap at noon, a girl had a seizure. We usually refer to such a situation as having a fit. My daughter's classmates cried, "S! S! She has a fit!" Feeling nervous, my daughter ran out of the classroom and cried, "Teacher! She has a fit!"

The girl told her mother about this incident, and she complained to me at a meeting, "It was improper for your daughter to say something like that." I had no idea what had happened at that time, so I said, "Really? If that is the case, I apologize to you. My daughter shouldn't say it that way. I had no idea that she might say something 
like that. After all, she may suffer from the same situation. I'll tell her to mind her wording."

I don't conceal anything from my daughter. She needs to understand the society. Nowadays, people are not so warm-hearted. There's nothing you can do about it. It is natural that people favor rich people. I told my daughter, "Don't take gifts from others or accept others' help indiscriminately, because you can't repay them. Don't count on others if you can do it by yourself. You don't need to strive for reciprocity like I do."

I have a weak heart now. Once, I asked my daughter, "What would you do if I don't feel well some day?" She said, "Mom, I will call 120 (the emergency number) immediately and feed you pills." I must tell her how to deal with it in advance. Otherwise, she would be perplexed in case of any emergency. If I need emergency treatment, I couldn't afford to waste any time. It will be helpful to both of us. I want to spend more time with her. Currently, my husband and I don't desire much. We only wish to be happy and joyful every day.

Q: Do you have any other hopes for your daughter?

S's mother: At her age, she should start thinking about getting married. We introduced her to many boys. But her disability certificate has both advantages and disadvantages. The advantage is that thanks to the certificate, she has settled down. She's happier, more confident, and healthier. But due to this certificate, others would hesitate to date her as she is jobless. Though some boys with a similar situation have an unsatisfactory job, their parents still look down upon my daughter. While in fact, I believe my daughter outperforms them in capability. She's simply weaker. When dating these people for some time, my daughter would find it difficult to communicate with them since she has her own opinions. So, she rejected them directly. She tends to go to extremes. We also thought of the possibility of finding her a husband who has no disability certificate, or who is slow but doesn't have an intellectual disability. But parents of those boys still worry that my daughter is simple-minded and unemployed.

Q: Do you want her to stay at the Sunshine Home all the time?

S's mother: Yes. Now my only wish is that she can live a happy and carefree life.

Q: Have you considered her future?

S's mother: We don't dare to. I hope the government will take care of her health and housing, etc. when my husband and I pass away.

$\mathrm{Q}$ : That concludes our interview. Thank you for your cooperation. I wish you all the best for the future.

S's mother: These kids are lucky (laughing).

\section{Interview with Miss S's Teacher (I)}

Interviewee: Teacher A from the Sunshine Home.

Interviewer and writer: Yi Zhang.

Interview date: December 7, 2016. 
Interview place: Sunshine Home of a subdistrict in Shanghai.

Q: Do you remember the situation when S arrived at the Sunshine Home for the first time?

Teacher: I don't know. You'd better ask Ms. Li. She joined the Sunshine Home before me. I came here a little over 3 years ago.

Q: Can you remember when you first saw her?

Teacher: She looked very good. I don't know what she was like when she first came here, because I joined later.

Q: How would you describe her personality?

Teacher: She's friendly, outgoing, and talkative (laughing).

Q: Does she have many friends here?

Teacher: Yes. She is the monitor here.

Q: I suppose she gets along well with her classmates. Are you impressed with any incidents?

Teacher: Nothing special. She learns faster than other students. After years of training, she is now good at artistic performances. She is keen to outdo others.

$\mathrm{Q}$ : Is she eager to outshine others?

Teacher: Yes. She would be upset if she lost in a competition.

Q: Is that also the case in class?

Teacher: Yes. She tends to strive for perfection. That's also the case when she is painting. So generally, she performs very well.

Q: Do you have any hopes for Miss S?

Teacher: I hope she'll be able to lead an independent life and further improve herself, so that she can find a job. We teachers don't want her or other students to stay here all the time. We hope all of them can be self-reliant someday. That's the best we can expect. If that happens, we won't mind even if the Sunshine Home is closed.

Q: Do you expect her to make progress in class?

Teacher: It is up to them. The most important thing is whether she is eager to learn. I can't do anything to improve her intelligence, but I can try to arouse her interest in learning. For example, she paints very well now. Other students would simply complain to teachers when they ran out of brushes or watercolors, but she will go shopping on her own. She's better than other students.

Q: Is she a good monitor?

Teacher: She is capable in every aspect, including learning and performing her tasks as the monitor.

Q: Thank you.

\section{Interview with Miss S's Teacher (II)}

Interviewee: Teacher B from the Sunshine Home.

Interviewer and writer: Yi Zhang. 
Interview date: December 7, 2016.

Interview place: Sunshine Home of a subdistrict in Shanghai.

Q: Nice to meet you. Were you here when Miss S first came to the Sunshine Home?

Teacher: Yes.

Q: What was she like?

Teacher: She thought she was here to be a volunteer, because her mother lied to her. She said, "I'm here to be a volunteer." She refused to join us. After all, she graduated from a specialized secondary school. It is natural that she didn't want to stay here. She thought she was different, she would become a volunteer.

Q: After she was enrolled, how was her performance?

Teacher: Not bad. She could express herself.

Q: What about her fine motor skills?

Teacher: Those were poor. She couldn't spread her fingers when we taught her finger gym and sign language. Her body was stiff.

Q: What about singing? Does she like singing?

Teacher: She sings well. She could sing well when she first came here. She can sing several pop songs very well.

Q: How long has she been here?

Teacher: Since 2008.

Q: Has she made any progress?

Teacher: Yes. She is much better now. At the beginning, she had great difficulties in memorizing things.

Q: Her classmates say she is always eager to outdo others.

Teacher: Yes, she always wants to excel.

Q: Can you remember any incidents that left a deep impression?

Teacher: She was ill-tempered. Previously, we had a male teacher. Once, he criticized her for improper remarks. She got mad and ran away to the bathroom, locking herself inside. I was terrified. She was a stubborn girl. If we wanted to criticize her, we needed to mind our wording and avoid other students.

Q: You couldn't criticize her in the presence of her classmates?

Teacher: No (shaking her head). We needed to talk to her in private. We always started with praise, otherwise, she couldn't bear it. Now, she seems much better in this regard. She likes to outperform others, especially in large events.

Q: Since she has been here, has she made significant progress in any specific aspect?

Teacher: She has made great progress in painting and dancing. In the past, when she needed to dance, she always said, "I can't. I'm weak. I can't do that." Now, she can control her temper.

Q: How would she react now, if you criticized her in public?

Teacher: Sometimes she still doesn't like it. In most cases, we just criticized her by name and don't say much. She would get our point right away. She will be fine as soon as she calms down.

Q: Does she lose her temper if she has difficulties while practicing dancing? 
Teacher: She tends to lose her temper if she can't learn the dance. She gets angry with herself.

Q: Does she continue practicing when she calms down?

Teacher: Yes. She knows how to calm herself down. She goes to the bathroom.

Q: Do you know how she does it?

Teacher: She washes her face with cold water in the bathroom. Sometimes, I wondered why she spent so much time in the bathroom, and I would go and check secretly. She didn't know. That's how she calms herself down.

Q: I suppose you won't criticize her under such circumstances?

Teacher: No, we won't. It is okay that she can calm down on her own.

$\mathrm{Q}$ : Is she the monitor in the class?

Teacher: Yes.

Q: How did she become the monitor?

Teacher: The students elected her.

$\mathrm{Q}$ : Is she recognized by all the students?

Teacher: Yes (Nodding).

Q: Does she have any special tasks as the monitor?

Teacher: She needs to write reports and take care of her classmates when they go on an outing.

Q: Do the students follow her instructions?

Teacher: Yes.

Q: Do you feel at ease leaving the students to her when they go on an outing?

Teacher: Yes. She does a good job and takes good care of her classmates, especially those with difficulties in walking and younger students. She helps her teacher a lot. She knows when to stop when they are crossing the road.

Q: Do you have any hopes for her?

Teacher: I hope she can control her temper and find a job. She has been hampered by her moderate intellectual disability.

Q: That concludes our interview. Thank you for your time.

\section{Interview with Miss S's Classmates}

Interviewee: Miss S's classmates A, B, and C at the Sunshine Home.

Interviewer and writer: Yi Zhang.

Interview date: December 7, 2016.

Interview place: Sunshine Home of a subdistrict in Shanghai.

Q: Are your familiar with Miss S?

Classmate A: Yes, I am.

Q: You have classes with her every day, right?

Classmate A: Yes.

$\mathrm{Q}$ : Is she nice?

Classmate A: Yes, she is. 
Q: Does she perform well in class?

Classmate A: Yes, she does.

Q: Is she the best? Do you consult her when you have questions?

Classmate A: (Shaking head).

Classmate B: Who are you talking about? Miss S?

Q: Yes, Miss S.

Classmate B: She is not bad. She always wants to outdo others. Whatever we are learning, she will master it.

$\mathrm{Q}$ : She wants to be the best, right?

Classmate A: She has been practicing a dance, because she doesn't want to affect the team due to her poor performance.

Classmate B: We are talking about Miss S. Come on (waving to classmate C).

Q: In your opinion, what are her strong points and weak points?

Classmate C: I shouldn't comment on her.

Q: It doesn't matter. You can say whatever you think.

Classmate C: She paints well and sings well.

Classmate B: She is conceited. If we have any unfavorable remarks about her, she becomes upset.

Q: What about her temper?

Classmate B: Not bad.

Q: Does she ever lose her temper?

Classmate B: Sometimes. She is generally kind to us.

$\mathrm{Q}$ : Is she the monitor? Do you think she is a good monitor?

Classmate B: Not bad.

Q: What does she do every day as the monitor?

Classmate B: Sometimes, the English teacher asks Miss S to check our English homework.

Q: Was she careful while checking your homework?

Classmate B: Yes, very careful.

Q: Could she identify your mistakes?

Classmate B: Yes.

Q: What else does she do?

Classmate C: We can ask her if we can't work out any problems.

Q: Does she teach you? Can she express herself clearly?

Classmates B and C: Yes, she can.

Classmate C: When we were painting, I asked her how to make dark green, she told me how to mix the paints.

Q: Does she have other tasks in addition to the one in English class?

Classmate B: She is good at singing.

Q: I mean, what else does she do as your monitor?

Classmate B: Sometimes, she checks our personal hygiene. She checked if we had clipped our nails.

Classmate C: And if we had brought our napkin.

Q: What would she do if you didn't clip your nails?

Classmate B: She would mark "bad" on her form. 
Q: And then?

Classmate B: That's all.

Q: What if you didn't have the napkin with you?

Classmate B: The teacher would ask the student to buy it.

$\mathrm{Q}$ : So, she tells your teacher that you didn't bring your napkin?

Classmate B: Yes.

Q: Does she have other tasks?

Classmate B: She helps check our homework.

Q: Nothing else?

Classmate B: Nothing.

\section{Interview with Miss S}

Interviewee: Miss S.

Interviewer and writer: Yi Zhang.

Interview date: March 7, 2018.

Interview place: Miss S's home.

Q: Do you still remember your experiences in kindergarten?

S: I don't recall much.

Q: It's OK. At primary school, which was your best subject?

S: I was good in Chinese. I got good marks on the Chinese exam.

Q: Did you find any of the subjects difficult?

S: Yes, I thought math and English were difficult.

Q: Did you like any teachers? Did you have any special experiences?

S: Teachers in primary school didn't impress me. But I was deeply impressed with a teacher in middle school.

Q: Can you tell me about the teacher?

S: She was my Chinese teacher, a straightforward woman from northeast China. She was kind to me, cared for me, and often encouraged me.

$\mathrm{Q}$ : Why were you impressed with the teacher?

S: Once, my mother was ill and needed to have a surgery at the hospital. But I had to go to school that day. I couldn't accompany my mom. I was absent-minded in class, which was noticed by my Chinese teacher. She asked me to read the article I wrote about my mom. I was so concerned about my mom that I cried. The teacher came to me immediately and asked me why I was crying. I told her about the surgery. She comforted me and said, "You are a good girl. Your mom will be fine." She told me not to worry and keep on studying. I appreciated her kind words.

Q: Are there any other teachers that you like or dislike?

S: Of course, I have teachers that I like. And I don't want to mention those I don't like. Let bygones be bygones.

Q: How did you get along with your classmates at primary school?

S: Generally, just so-so. 
Q: Did you have close friends at that time? Someone you often played with or went home together after school.

S: I don't think I did.

Q: Were you close with any of your classmates in middle school?

S: I don't think so.

Q: Your mother mentioned that before the high school entrance exam, your parents worked together with you at night to prepare for the exam. Can you recall any such experiences?

$\mathrm{S}$ : Of course. I remember that before examinations at primary school and middle school and the high school entrance exam, they were more nervous than me. They stayed up late and helped me with my homework. They wouldn't sleep unless I went to bed. Since the second grade in middle school, they didn't need to sit by me when I did my homework.

Q: Did your parents scold or encourage you when you got poor marks in exams?

S: They didn't scold me when I got poor marks in exams. Instead, they would encourage me and tell me to work harder to make progress.

Q: I see. Did you still have great academic pressure at the specialized secondary school?

S: I didn't feel as much pressure as before.

Q: Your mom didn't tell me much about your experiences at the specialized secondary school. So, I have an additional question for you. What courses did you take?

S: During that period, in addition to the compulsory courses of Chinese, math, and English, I also had politics, philosophy, history, physics, and chemistry.

Q: That's a lot. The school prepared you for job seeking, right?

$\mathrm{S}$ : Yes. I majored in e-commerce, so that I could become a cashier after graduation.

Q: Were your marks comparatively better at this school? Your mom mentioned that you worked hard during that period.

S: She was right. I worked very hard. I got better grades in courses for liberal arts than science.

Q: Did you get along well with your classmates?

$\mathrm{S}$ : Not bad. We had been together since the military training outside school. But I wasn't confident in those days and I didn't talk much. I didn't often communicate with most of my classmates, except a few.

Q: Do you remember how your internship was assigned?

$\mathrm{S}$ : At the beginning, the school assigned me to work as an intern cashier at a Lotus Market in Sanlin. I didn't go there because of time constraints and long commuting distance. Then, I was assigned to work as a conductor and courier at an office on Tianmu East Road for Shanghai Airlines. My parents were concerned for my safety because I needed to carry a lot of money to work and the place was far away from my home. In addition, I couldn't come home on time. So, my parents asked me to quit. After that, I took internships at KFC and a supermarket, where I was formally employed by the latter for some time, till I lost my job during the financial crisis in 2008.

Q: Compared with your experience at work, did anything change after you came to the Sunshine Home? 
S: I think I am happier here. At least, I don't feel any pressure.

Q: I know you are a monitor at the Sunshine Home. Can you share some experiences that give you a sense of achievement?

S: I've been despised by others outside the Sunshine Home, but everyone is equal here. The teachers here care for me and my classmates respect me. It is the feeling of being respected and trusted that gives me the greatest sense of achievement.

Q: Do you have any hopes or dreams for the future?

S: I have three wishes. First, I hope there will be more non-profit organizations to care for us and interact with us. Second, I hope the Sunshine Home will flourish. The last and most important one is that I hope my parents will have a long and healthy life, so that we can be together all the time.

\section{Observation of Miss S at Sunshine Home}

Observation date: 9:00-15:00, December 7, 2016.

Observation place: A Sunshine Home of a subdistrict in Shanghai.

Observer and writer: Yi Zhang.

\begin{tabular}{|c|c|c|}
\hline Time & Activity & Remarks \\
\hline $8: 55$ & $\begin{array}{l}\text { S came into the classroom and put her } \\
\text { bag away }\end{array}$ & $\begin{array}{l}\text { The class begins at 9:00 in the } \\
\text { morning at the Sunshine Home }\end{array}$ \\
\hline 9:05 & Radio gymnastics exercises & $\begin{array}{l}\text { S stood in the first row with standard } \\
\text { and coordinated moves. She didn't } \\
\text { need to watch the teacher's } \\
\text { demonstration }\end{array}$ \\
\hline $9: 10$ & $\begin{array}{l}\text { After the radio gymnastics exercises, } \\
\text { S took off her coat and started joint } \\
\text { exercises }\end{array}$ & $\begin{array}{l}\text { The joint exercises were practiced to } \\
\text { the rhythm of music. The moves were } \\
\text { slow but powerful }\end{array}$ \\
\hline $9: 15$ & $\begin{array}{l}\text { S adjusted the volume of the television } \\
\text { in the classroom and selected a song }\end{array}$ & $\begin{array}{l}\text { She was preparing for the dancing } \\
\text { class. The classroom was in chaos as } \\
\text { students had just finished the joint } \\
\text { exercises }\end{array}$ \\
\hline $9: 17$ & $\begin{array}{l}\text { Students danced to the music. } \mathrm{S} \text { was } \\
\text { the leading dancer of the second group }\end{array}$ & \\
\hline $9: 20$ & $\begin{array}{l}\text { S stood in a corner of the classroom } \\
\text { and chatted with her classmates. They } \\
\text { checked the collars of each other and } \\
\text { discussed whether the collars were } \\
\text { suitable }\end{array}$ & \multirow{2}{*}{$\begin{array}{l}\text { When the dancing teacher explained } \\
\text { the moves to students of the first } \\
\text { group, S listened carefully. S nodded } \\
\text { and smiled when her classmates did } \\
\text { the right move. She laughed out loud } \\
\text { and then thought it over if there were } \\
\text { any mistakes }\end{array}$} \\
\hline $9: 25$ & $\begin{array}{l}\text { S went to another classroom to fetch a } \\
\text { vest and put it on. She combed her hair }\end{array}$ & \\
\hline
\end{tabular}


(continued)

\begin{tabular}{|c|c|c|}
\hline Time & Activity & Remarks \\
\hline $9: 35$ & $\begin{array}{l}\text { S chatted with her classmates about } \\
\text { the potted plants at the window }\end{array}$ & \\
\hline $9: 41$ & $\begin{array}{l}\text { S danced and practiced the moves } \\
\text { following the demonstration of the } \\
\text { teacher }\end{array}$ & S's moves were basically correct \\
\hline $9: 45$ & $\begin{array}{l}\text { The teacher corrected the details of } \\
\text { S's moves over and again }\end{array}$ & $\begin{array}{l}\text { S understood soon after the teacher's } \\
\text { explanation, but she made the same } \\
\text { mistake when they danced to the } \\
\text { music }\end{array}$ \\
\hline $9: 57$ & $\begin{array}{l}\mathrm{S} \text { took off her vest after the teacher } \\
\text { asked if she felt hot }\end{array}$ & Rehearsal of the first dance was over \\
\hline 10:00 & $\begin{array}{l}\text { S adjusted the volume of the television } \\
\text { in the classroom and selected a song. } \\
\text { Instructed by the teacher, she went } \\
\text { back to her position }\end{array}$ & $\begin{array}{l}\text { She was preparing for the second } \\
\text { dance }\end{array}$ \\
\hline 10:07 & $\begin{array}{l}\text { S looked at her reflection on the white } \\
\text { board to check if her moves were } \\
\text { satisfactory }\end{array}$ & \\
\hline 10:13 & $\begin{array}{l}\text { S sat on a chair in front of the } \\
\text { classroom, drank some water, and } \\
\text { chatted with her classmates }\end{array}$ & $\begin{array}{l}\text { The dancing class was over. Students } \\
\text { were taking a break }\end{array}$ \\
\hline 10:20 & $\begin{array}{l}\text { Students were called together to set } \\
\text { the desks and chairs }\end{array}$ & \\
\hline 10:26 & $\begin{array}{l}\mathrm{S} \text { watched her classmates playing } \\
\text { table tennis }\end{array}$ & \\
\hline 10:28 & S played table tennis & \\
\hline $10: 38$ & $\begin{array}{l}\mathrm{S} \text { washed her spoon and queued for } \\
\text { the meal. She took the meal to her seat } \\
\text { and joined the queue for soup }\end{array}$ & \\
\hline $10: 40$ & $\begin{array}{l}\text { S finished her meal. She didn't eat } \\
\text { sheet jelly, which she gave to a } \\
\text { classmate }\end{array}$ & $\mathrm{S}$ devoured her meal in an intense way \\
\hline $10: 55$ & $\begin{array}{l}\text { S put her meal box away and cleaned } \\
\text { her seat }\end{array}$ & \\
\hline 11:00-13:55 & Rest & $\mathrm{S}$ rested on a sofa \\
\hline $13: 58$ & $\begin{array}{l}\text { S went back to the classroom and put } \\
\text { her stationery on the desk }\end{array}$ & $\begin{array}{l}\text { The afternoon class begins at } 14: 00 \text { at } \\
\text { the Sunshine Home }\end{array}$ \\
\hline $14: 00$ & $\begin{array}{l}\text { S announced, "Stand up! One, two, } \\
\text { three!" }\end{array}$ & $\begin{array}{l}\text { She was performing her tasks as the } \\
\text { monitor }\end{array}$ \\
\hline 14:05 & $\begin{array}{l}\text { According to the teacher's } \\
\text { explanation, } S \text { painted a pair of scales. } \\
\text { She reminded her desk mate that the } \\
\text { circles should be the same size }\end{array}$ & $\begin{array}{l}\text { They were having an art lesson. The } \\
\text { first part was about the weight of } \\
\text { colors }\end{array}$ \\
\hline
\end{tabular}


(continued)

\begin{tabular}{|c|c|c|}
\hline Time & Activity & Remarks \\
\hline 14:10 & $\begin{array}{l}\text { S put a cup on the paper, traced the } \\
\text { bottom of the cup and drew two circles }\end{array}$ & \\
\hline 14:13 & $\begin{array}{l}\text { S chose the colors. She extruded } \\
\text { pea-size white and yellow from the } \\
\text { tubes and mixed them }\end{array}$ & $\begin{array}{l}\text { She wanted to make a pale-yellow } \\
\text { color }\end{array}$ \\
\hline 14:15 & $\begin{array}{l}\mathrm{S} \text { asked the teacher whether the color } \\
\text { she made was satisfactory and got a } \\
\text { positive answer }\end{array}$ & \\
\hline 14:16 & $\begin{array}{l}\text { S painted the circles with the color she } \\
\text { had made }\end{array}$ & $\begin{array}{l}\text { She traced the circles, then painted } \\
\text { them. The color was even }\end{array}$ \\
\hline 14:18 & $\begin{array}{l}S \text { extruded pea-size black and yellow } \\
\text { from the tubes and mixed them }\end{array}$ & $\begin{array}{l}\text { She wanted to make a dark-yellow } \\
\text { color }\end{array}$ \\
\hline $14: 20$ & $\begin{array}{l}\text { S asked the teacher whether the color } \\
\text { she made was satisfactory. The } \\
\text { teacher suggested that she should add } \\
\text { some more black. S thought that there } \\
\text { might be too much black }\end{array}$ & \\
\hline $14: 23$ & $\begin{array}{l}\text { S asked the teacher again whether the } \\
\text { color she made was light enough. She } \\
\text { discussed with her classmate the } \\
\text { shade of color and the position of the } \\
\text { two circles }\end{array}$ & \\
\hline $14: 28$ & $\begin{array}{l}\text { S drew another two circles, mixed } \\
\text { colors and painted them }\end{array}$ & $\begin{array}{l}\text { In her first painting, the two spheres of } \\
\text { different shades were on the same } \\
\text { level. In the second painting, she } \\
\text { considered the relationship between } \\
\text { the shades of colors and the position } \\
\text { of the two spheres. The bright sphere } \\
\text { was above the dark one in the second } \\
\text { painting }\end{array}$ \\
\hline $14: 35$ & $\begin{array}{l}\text { S continued to paint. She used the dark } \\
\text { green color she had made to show the } \\
\text { teacher the color of "bitterness" }\end{array}$ & $\begin{array}{l}\text { The teacher proceeded to the next part } \\
\text { of the lesson: taste of colors }\end{array}$ \\
\hline $14: 36$ & $\begin{array}{l}\text { S was still working on the first part of } \\
\text { the lesson }\end{array}$ & $\begin{array}{l}\text { The teacher asked her to stop and start } \\
\text { the second part }\end{array}$ \\
\hline $14: 39$ & $\begin{array}{l}\text { S used a ruler to draw a table on her } \\
\text { picture book, with respective space for } \\
\text { colors representing bitterness, } \\
\text { sweetness, sourness, spiciness, } \\
\text { saltiness, and tastelessness }\end{array}$ & The table was neat and clean \\
\hline $14: 42$ & $\begin{array}{l}\text { S discussed with her classmates about } \\
\text { their perception of colors. In their } \\
\text { opinion, soy sauce was salty, which } \\
\text { can be represented by the color black, } \\
\text { and balsam pear was bitter, which can } \\
\text { be represented by the color green }\end{array}$ & \\
\hline
\end{tabular}


(continued)

\begin{tabular}{|c|c|c|}
\hline Time & Activity & Remarks \\
\hline $14: 43$ & $\begin{array}{l}\text { S painted the space representing } \\
\text { bitterness with dark green and then } \\
\text { added some light green according to } \\
\text { the teacher's advice }\end{array}$ & \\
\hline 14:46 & $\begin{array}{l}\text { S mixed the color for bitterness and } \\
\text { sweetness and painted the } \\
\text { corresponding spaces in the table }\end{array}$ & $\begin{array}{l}\text { Bitterness: dark green and light green. } \\
\text { Sweetness: hot pink and coral }\end{array}$ \\
\hline $14: 49$ & $\begin{array}{l}\text { S mixed the color for spiciness and } \\
\text { saltiness and painted the } \\
\text { corresponding spaces in the table }\end{array}$ & $\begin{array}{l}\text { Spiciness: red and green. Saltiness: } \\
\text { light green and dark green }\end{array}$ \\
\hline $14: 50$ & $\begin{array}{l}\mathrm{S} \text { talked to her classmates about light } \\
\text { colors }\end{array}$ & \\
\hline $14: 53$ & $\begin{array}{l}\mathrm{S} \text { walked out of the classroom to } \\
\text { replace the water for washing brushes } \\
\text { and washed her brushes }\end{array}$ & She then painted white \\
\hline 14:54 & $\begin{array}{l}\text { S's hand was smeared with the paint } \\
\text { when she extruded yellow color. She } \\
\text { went out to wash her hands and came } \\
\text { back }\end{array}$ & She was running out of yellow paint \\
\hline $14: 57$ & $\begin{array}{l}\text { Class was over. S announced, "Stand } \\
\text { up!" }\end{array}$ & $\begin{array}{l}\text { She continued to paint as she made the } \\
\text { announcement }\end{array}$ \\
\hline $14: 58$ & S sat down and continued to paint & $\begin{array}{l}\text { After the class was over, } S \text { continued } \\
\text { to paint till she finished the work }\end{array}$ \\
\hline 15:00 & $\begin{array}{l}\text { S packed her bag, put on her coat and } \\
\text { went home }\end{array}$ & \\
\hline
\end{tabular}

\section{Translated by Min Cui}

Open Access This chapter is licensed under the terms of the Creative Commons AttributionNonCommercial-NoDerivatives 4.0 International License (http://creativecommons.org/licenses/bync-nd/4.0/), which permits any noncommercial use, sharing, distribution and reproduction in any medium or format, as long as you give appropriate credit to the original author(s) and the source, provide a link to the Creative Commons license and indicate if you modified the licensed material. You do not have permission under this license to share adapted material derived from this chapter or parts of it.

The images or other third party material in this chapter are included in the chapter's Creative Commons license, unless indicated otherwise in a credit line to the material. If material is not included in the chapter's Creative Commons license and your intended use is not permitted by statutory regulation or exceeds the permitted use, you will need to obtain permission directly from the copyright holder.

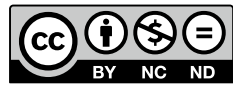

